Cinémas

Revue d'études cinématographiques

Journal of Film Studies

\title{
The New Film History as Media Archaeology
}

\section{Thomas Elsaesser}

Volume 14, numéro 2-3, printemps 2004

Histoires croisées des images. Objets et méthodes

URI : https://id.erudit.org/iderudit/026005ar

DOI : https://doi.org/10.7202/026005ar

Aller au sommaire du numéro

Éditeur(s)

Cinémas

ISSN

1181-6945 (imprimé)

1705-6500 (numérique)

Découvrir la revue

Citer cet article

Elsaesser, T. (2004). The New Film History as Media Archaeology. Cinémas, 14(2-3), 75-117. https://doi.org/10.7202/026005ar

\section{Résumé de l'article}

Cet article évalue l’impact des technologies numériques sur notre conception de l'histoire du cinéma. Alors que la " nouvelle histoire du cinéma " a revitalisé les études des « origines » du cinéma, elle n’a pas encore montré autant de succès dans l'analyse de la conjoncture multimédiatique du dernier tournant de siècle. Cet article propose un nouveau modèle historiographique,

l'« archéologie des médias ", afin de dépasser l'opposition entre vieux médias et nouveaux médias, mise à mal par les expériences médiatiques contemporaines. Le terrain des pratiques audiovisuelles a besoin d'être à nouveau cartographié : il faut clarifier les concepts d'incorporation, d'interface, de narration, de diégèse et donner une nouvelle impulsion à l'étude des utilisations du dispositif audiovisuel en dehors du secteur du seul marché du divertissement. 


\section{The New Film History as Media Archaeology}

\section{Thomas Elsaesser}

\section{RÉSUMÉ}

Cet article évalue l'impact des technologies numériques sur notre conception de l'histoire du cinéma. Alors que la "nouvelle histoire du cinéma» a revitalisé les études des "origines" du cinéma, elle n'a pas encore montré autant de succès dans l'analyse de la conjoncture multimédiatique du dernier tournant de siècle. Cet article propose un nouveau modèle historiographique, l'«archéologie des médias", afin de dépasser l'opposition entre vieux médias et nouveaux médias, mise à mal par les expériences médiatiques contemporaines. Le terrain des pratiques audiovisuelles a besoin d'être à nouveau cartographié: il faut clarifier les concepts d'incorporation, d'interface, de narration, de diégèse et donner une nouvelle impulsion à l'étude des utilisations du dispositif audiovisuel en dehors du secteur du seul marché du divertissement.

\section{ABSTRACT}

The article assesses the impact of digital technologies on our understanding of film history. While the "New Film History" has revitalized the study of the cinema's "origins," it has not yet proven itself equally successful in analyzing the subsequent turn-of-the-century multimedia conjuncture. Faced with this challenge, the essay makes a case for a new historiographical model, "Media Archaeology," in order to overcome the opposition between "old" and "new" media, destabilized in today's media practice. The field of audio-visual experience needs to be re-mapped, clarifying what is meant by embodiment, interface, narrative, diegesis, and providing new impulses also for the study of non-entertainment uses of the audio-visual dispositif. 


\section{Introduction}

For more than two decades now, it has become commonplace to discuss the cinema in terms that acknowledge its function as a medium that has introduced a universally comprehensible and yet deeply contradictory logic of the visible. So ubiquitous is the moving image in our urban environment that its impact cannot simply be located in individual films, however many canons of cult classics or masterpieces we choose to construct. In making much of human life and history "visible," the cinema has also created new domains of the "invisible." Key elements of cinematic perception have become internalised as our modes of cognition and embodied experience, such that the "cinema effect" may be most present where its apparatus and technologies are least perceptible. Cinema's role in transforming the past and historical representation into collective memory is now a matter of intense debate, ${ }^{1}$ while its "invisible hand" in our affective life and in our modes of being-in-the-world-our ontologies-has preoccupied psychoanalysis and philosophy. ${ }^{2}$ Likewise, theories of cinematic spectatorship, initially elaborated around class and (immigrant) ethnicity, have been extended to gender, race and other forms of cultural identity. Broadened out to encompass issues of modernity, mass-consumption and metropolitan life, research on the spectators of film and television has also been asking political questions about media citizenship, or worried about the ethics of performativity, where authenticity is "hiding in the light." At the same time, cinema as perception, thought, affect and body has moved centre-stage in film theory, debated by followers of Gilles Deleuze as passionately as by cognitivists, while the relation between seeing and knowing is at the conceptual core of much contemporary video and installation art. The cinema is part of us, it seems, even when we are not at the movies, which suggests that in this respect, there is no longer an outside to the inside: we are already "in" the cinema with whatever we can say "about" it! " $^{3}$

This renewed reflection about "what is cinema" - some fifty years after André Bazin last put this question-may initially have been occasioned by the centenary of the first public presentation of the Lumière cinématographe celebrated in 1995. But 
it is safe to assume that such inquiry is made necessary and urgent also by the growing realisation that by the turn of the millennium, the technologies of sound and vision had undergone a decisive shift in paradigm. This shift requires a new mapping of the moving image, and a new location of cinema in culture, for which the term "digitisation" suggests itself as the most obvious common denominator, but not always as the most convincing analysis. For instance, it is widely assumed that the convergence between image-, audio- and print media is inevitable, modifying and even overturning our traditional notions of cinema. But the assumption rests on several unstated premises both about this convergence and about the separate histories of cinema, television and electronic audio-vision. While it may be true that the analysis of digital media cannot simply be treated as an extension of film studies as currently practised, it is not at all proven that digitisation is the reason why the new media present such a challenge, historically as well as theoretically, to our idea of cinema. Perhaps it merely forces into the open inherent flaws and contradictions, shortcomings and misconceptions in the accepted picture? If so, we need to ask further questions. Does the digital image constitute a radical break in the (Western) culture of imaging, or is it merely a technological continuation of a long and complex history of mechanical vision, following a historical logic (of "improvement," adaptation, emulation and remediation) which traditional film theory has not yet fully encompassed? How aware have we been of culturally distinct modes of representation and the technologies as well as institutions regulating the "life-cycles" of these modes? Have we been fixated too exclusively on "the image," and forgotten about sound; have we been concentrating on films as texts, and neglected the cinema as event and experience? Is film studies vulnerable because its idea of film history has operated with notions of origins and teleology that even on their own terms are untenable in the light of what we now know, for instance, about the so-called origins of cinema and its early (i.e. pre1917) practice?

In what follows I want to treat the so-called "digital revolution" as a moment of rupture, to be sure. Yet it does not follow 
that this rupture must be (in the first instance) technological, or even a matter of aesthetics. Besides being a powerful device of signal conversion, a new standard in the techniques of information, and a process of inscription, storage and circulation, "the digital" in this context is also a metaphor: more properly, a metaphor for the discursive space and enunciative position of rupture itself. Rather than directly enter the debate about whether digitisation is merely an improved or accelerated technology of the visible and the audible, or whether it is indeed a radical, qualitative change in their respective ontologies, I take digital media as the chance to rethink the idea of historical change itself, and what we mean by inclusion and exclusion, horizons and boundaries, but also by emergence, transformation, appropriation, i.e. the opposite of rupture. It permits me to once more query what I think I know already, namely the specificity of film and the role moving images occupy within the history of modernity and the mass media. The digital makes the place from which I speak a space at once a "zero-degree" and a "ground zero." It acknowledges the situation just sketched: there may not be an "outside" to the "inside" from which to derive a fixed position or a critical (di)stance, but also there may not be a "before" and "after" the digital in the way we speak of before and after Christ. Without an eschatological-ontological break, we can scrutinise not only the chronological-linear models of film history we have been working with, but also their opposite: the notion of "origins" and "beginnings." For reasons that I hope will become clear, I propose to call this alternative approach "film history as media archaeology."

\section{Early Cinema as Key to the New Media Paradigms?}

A first step would be to see whether the insights gained over the past twenty years from the study of early cinema could lead, if not to new paradigms, then at least to a better understanding of the actual or apparent changes in audio-visual media, on the far side of boosterist future-speak, as well as of an equally blind cultural pessimism. ${ }^{4}$ For this, I am suggesting, we have to reexamine the idea of continuity and rupture, as well as the dynamics of convergence and divergence, of synergy and self- 
differentiation. To cite an obvious example: given the rupture posited by the New Film History between early cinema (the cinema up to 1917) and the classical narrative cinema under Hollywood hegemony (itself replaced by the "New Hollywood" of the 1970s), scholars have been trying to accommodate the continuities as well. ${ }^{5}$ The vocabulary of postmodernism proved to be one solution, because it supplanted the discourses of revolution and epistemic breaks with those of transformations and transitions, of pastiche and parody, of remediation and appropriation. These helped to comprehend, in the study of mainstream cinema, the surprising kinds of survival and afterlife, of recycling and retrofitting, that seem to have kept Hollywood practice so stable over nearly a hundred years. But is Hollywood changing in order to stay the same (the way Burt Lancaster put it, refering to the bourgeoisie, in Visconti's The Leopard), or have the body-snatchers of global finance turned the stars and genres of classical cinema into pod-personalities and pseudoevents, to the acquiescence of all concerned (as critics of the blockbuster era would have it)? Where are the ruptures, in light of the interpenetration of cinema, television and electronic images in mainstream entertainment? If it is easy to yield to the shared presumption of convergence, of multi-, hyper- and intermediality, do we mean by this a new universalism of symbolic languages (or "codes"), once more reviving the fantasy of the moving image as the "Esperanto of the eye?" Or does convergence merely designate the strategic alliances between the owners of traditional media, where multinational business conglomerates (Time Warner/AOL, News Corporation, Bertelsmann) invest in the print-media (newspaper and publishing), in television (terrestrial and cable), in the film business, in audio-recording media and delivery systems such as the internet, expecting to effect "synergies" that will re-establish the old trusts and monopolies of the studio-era, while further globalising their reach? Do we see convergence as a broad sweep of universal aspirations of leisure and entertainment, entailing common visual icons and modes of representation? Or, on the contrary, do we witness the emergence of powerful sectional interests, of niche markets, of regional and local enclaves and the ever more 
self-differentiating trends typical of complex systems and networks?

This is where a look at early cinema suggests alternative models for thinking both change and continuity, both the concentration of power and the very divergent practices adopted by "users." The so-called origins and pre-history of the cinema have attracted scholars precisely because of these debates. On the one side, the sudden, almost simultaneous "birth" of the movies at the turn of the previous century. And on the other, the heterogeneity, the long gestation, the uneven developments and the fact that very divergent conceptions of what the cinema was or could be existed side by side, not to mention the co-presence of different media-forms and practices such as vaudeville, panoramas and dioramas, stereoscopic home entertainment, Hale's tours and world fairs. Both pictures-here: determinism and teleology; there: an almost prelapsarian picture of creative chaos- have been checked and corrected by a tendency to represent early film history as a series of (more or less) distinct, selfcontained moments. Noël Burch's formulation of a "primitive mode of representation" and an "institutional mode of representation" was part of a trend towards other kinds of boundary drawing, such as European art cinema versus mainstream commercial cinema, "classical" versus "postclassical" cinema, and other bi-polar models. The penchant for emphasising discontinuity and epistemic breaks was itself a Foucault-inspired reaction against traditional (or "old") film history's tacit assumption of linear progress, either in the form of a chronological-organic model (e.g. childhood-maturity-decline and renewal), a chronological-teleological model (the move to "greater and greater realism"), or the alternating swings of the pendulum between (outdoor) realism and (studio-produced) fantasy.

Countering these traditional modes of writing film history was one reason why cinema studies in the last decades has devoted itself so intensively to early cinema, and the "emergence" of the medium. By demonstrating the alterity and otherness, but also insisting on the sophistication, of early cinema, it was possible to disprove implicit notions of infancy, tentativeness or incompetence found in standard histories. But when 
Noël Burch, in his 1978 essay, played Edwin S. Porter off against D.W. Griffith as the true pioneer of early cinema, he spoke above all in the name of a film-aesthetic avant-garde that wanted to go back to the cinema prior to Griffith in order to challenge, at least conceptually if not in practice, Hollywood's dominance (and that of the narrative feature film). The rediscovery of the "primitive mode" seemed like a vindication of more than fifty years' indefatigable efforts on the part of the avant-garde in both North America and Europe to rethink the basis of "film language." It raised the hope of retiring once and for all the notion that the development of cinema towards fictional narrative in the form of representational illusionism had been its pre-ordained destiny. As Burch liked to say: "it could have been otherwise..."

The polemic was the more timely since during the 1970 s speculation was rife about the decline of the hegemony of classical cinema from an altogether different perspective. The changes in film reception, i.e. the dwindling audiences for both first and second-run theatres in the 1960s and 1970s and the parallel regrouping of the family audience in the home and around television, indicated that the cinema was indeed being replaced. It was even argued that, due to the combination of television, the video camera and the domestic VCR, cinema had become obsolete. This encouraged especially left-wing media historians to try and integrate film history (assuming the widely propagated and lamented "death of cinema" as a fait accompli) into the broader cultural and economic context of the entertainment and consciousness industries. Siegfried Zielinski for instance, a German historian of the video-recorder, spoke of cinema quite generally as an "intermezzo" in the history of "Audiovisions." At the other end of the scale, the revival of Hollywood since the 1980s around the re-invention of special effects was also interpreted as a breaking away from the classical cinema's form of narrativerealism-illusionism, with its psychologically motivated characters and single diegesis anchored in time-space verisimilitude. What in the very early years of the last century had been the attraction of the technical apparatus itself — with its miraculous capacity to bring images to life and to animate photographed 
street-scenes, panoramic landscape views or human beings in their everyday surroundings-became by the end of the century the attraction of digital images and fantasy worlds, which also cast a spell on audiences and drew from them gasps of disbelief. Then as now, the eye was seeing things that the mind could barely comprehend. As an "aesthetics of astonishment" (Gunning 1989) took over from realism, the cinema seemed to be witnessing the return of a "cinema of attractions" (Gunning 1990).

\section{The Cinema of Attractions: Early Cinema, Avant-garde, the Post-Classical and Digital Media}

By taking up the notion of the "cinema of attractions," the discussion of this contemporary cinema of (digital) special effects found a certain genealogical place and stylistic orientation within an overall film and media history that privileged early cinema. ${ }^{8}$ As will be remembered, Tom Gunning and André Gaudreault had launched the phrase in 1985, in a sense summarising the debates between Burch, Charles Musser, and Barry Salt over the kinds of otherness and degrees of autonomy manifested by the cinema up to the First World War. Opposed to the "cinema of narrative integration," the "cinema of attractions" named the different features of the early cinema's distinctive mode, quickly displacing not only Burch's "primitive mode of representation," but also Musser's "exhibition-led editorial control," as well as Gaudreault's "monstration" and other, similarly aimed locutions. Not the least of the reasons why Gunning's formulation won the day was that at the end of his article he speculated that this mode may offer surprising parallels with contemporary filmmaking, where physical spectacle seems once more to gain in importance over carefully motivated and plotted narrative. Action-oriented heroes predominated over psychologically rounded characters, heralding a performative style, again similar to early cinema practice, where spectacular set pieces were responsible for a discontinuous rather than a smooth visual experience. More generally, one could extrapolate from Gunning's argument that realism in current cinema was subordinated to differently motivated types of fantasy and spectacles of excess, 
again not unlike the rough-and-tumble of early chase films, farces and slapstick. What the frantic pursuit or the graphic humour was to early film genres, so the roller coaster rides, the horror, slasher, splatter, or kung-fu sequences to contemporary cinema: skilfully mounted scenes of mayhem and destruction. These scenes do not have to build up the classical arch of suspense, but aim for thrills and surprise, which in the action genres are delivered at close range and with maximum bodily impact. As in early cinema, audiences expect such set pieces, which suspend or interrupt the narrative flow, and in this sense externalise the action. The cinema of attractions, by focusing less on linear narrative progression, manages to draw the spectator's attention to a unique form of display. ${ }^{9}$

Following these thoughts further and extending them to the realm of the digital, it would appear that the electronic, socalled interactive media also fall under the heading of the cinema of attractions, by encouraging viewers to immerse themselves in the image as total environment rather than to relate to the screen as a window on the world. "Attraction" also seemed an apposite term to describe the thrills of video-games, because they, too, foster a different contact space between player and the screen as interface. Finally, parallels could be drawn between today's Hollywood big budget feature films as multi-functional, multi-purpose, multi-platform audiovisual products for the global entertainment market (merchandising, music, fashion) and the surprisingly multi-medial and international context of early cinema. For the event-driven appeal of the modern blockbuster, with its ability to colonise social and media space with advertising and promotional "happenings," also has its predecessors from the 1910s onwards. For instance, we see the same kind of thinking behind the very successful Passion films of Pathé, the elaborate publicity around certain films specially produced for Christmas release, or the large-scale disaster films that Italian and German producers first specialised in. ${ }^{10}$ Everywhere, it seems, references back to early cinema practice offered themselves, which in turn made these nearly forgotten films appear strangely familiar and once more popular in retrospectives and at festivals. ${ }^{11}$ 
Thus, Gunning's initial reflections on the relation between pre-1917 cinema and the avant-garde have been used for a much broader hypothesis, suggesting that early cinema, understood as a cinema of attractions, can encourage us to think of film history generally as a series of parallel (or "parallax") histories, organised around a number of shifting parameters which tend to repeat themselves periodically, often manifesting a relation of deviance to norm, or the subversion of a standard. ${ }^{12}$ Coming some ten years after "Visual Pleasure and Narrative Cinema," which established a gendered opposition between spectacle and narrative and between two different modes of display (voyeurism and fetishism), the "cinema of attractions" took over from Laura Mulvey (whom Gunning cites in his essay) as the magic formula of film studies, the Sesame opening new doors of perception, critique and classification.

There is no doubt that the binary pairs "spectacle/narrative," "numbers principle/linear action," "interaction with the audience/passive reception," etc. provided a typology, which proved most effective as a conceptual grid for initially sorting and slotting in the new modes of cinema, such as blockbusters, but also for post-cinematic media-effects and practices, such as videogames. It helped to keep the new digital media products within the theoretical reach of film studies and cinema history. But by positing similarities between two "cinemas of attractions" on either side of classical narrative, this intervention in the New Film History took a further step. The assertion that early cine$\mathrm{ma}$ is closer to post-classical cinema than it is to classical cinema also reverses the relation of norm and deviance. Now early cinema appears-flanked by the powerful, event-driven and spectacle-oriented blockbuster cinema - as the norm, making the classical Hollywood cinema seem the exception (or "intermezzo"). The "cinema of attractions" thus joins in the attack on classical cinema which, since the 1960s, has been fought, in quick succession, by the American avant-garde, by Althusserian ideological criticism, by feminist Lacanian film theory, by Gramsci and Foucault-inspired cultural studies, and-as indicated in the reference to Zielinski-by television history and media theory of the kind also represented by Friedrich Kittler. But such a move 
need not only be taken polemically and as a polarising strategy. It could lead to suspending all norm/deviancy models of thinking, and append a question mark to all teleological film and media histories. In the spirit of our attempt to treat early cinema studies as a possible template for the study also of other periods of film history and other paradigms of cinema practice, this would mean applying even more radically some of the founding gestures of the New Film History. For instance, its break with a linear causality in cinema historiography should also be applied to the argument that the new and old media are destined to converge into a digital "hypermedium," and its argument in favour of alterity and discrete epistemes should alert us to the non-congruent and a-synchronous moments today. In sum, the problems and perspectives of the digital media perhaps supply more pertinent reasons for returning to early cinema and the methodologies by which it has been studied than any polemical attempt to dislodge classical cinema. Ideally, the task would be to recast film history as a whole: whether this implies setting oneself off from (previous theories of) classical cinema is an important point, but it cannot be the main aim of the exercise.

\section{Media Archaeology I: Film History between Shifting Teleologies and Retroactive Causalities}

One such case where a contemporary media perspective, sensitised by the proliferation, rapid change and competition among different audio-visual dispositifs, has changed the way we regard the past is in the question of the "emergence" of the cinema. Among proponents of the New Film History, it is now generally accepted that the cinema has too many "parents," as well as too many "siblings," for its origins and identity to add up to a single (linear) history. That this insight is owed to our present situation can be seen by a simple test: open any textbook that is older than twenty years and look up the genealogies of the techniques and technologies required for the "invention of cinema." There, the history of photography, the history of projection and the "discovery" of persistence of vision are listed as the triple pillars that sustain the temple of the Seventh Art. Or, to change the metaphor: they appear as the three major 
tributaries that finally_miraculously but also inevitably_-join up around 1895 to become the mighty river we now know as the cinema. Today we notice, above all, the other sources upstream not included: all that is absent, missing or that has been suppressed in the genealogical chart. Sound, for instance, since the silent cinema was rarely if ever silent, in which case: why is the history of the phonograph not listed as another tributary? And as we now understand the cinema as part of a multimedia environment, how about the telephone as an indispensable technology? Radio-waves? Electro-magnetic fields? The history of aviation? Do we not need Babbage's difference engine ranged parallel to his friend Henry Fox-Talbott's Calotypes or Louis Daguerre's sensitised copper plates? These questions in themselves show how much our idea-and maybe even our definition - of cinema has changed even without appealing to digitisation as a technology, which is nonetheless implicit as a powerful "perspective correction" and thus counts as an impulse in this retrospective re-writing of the past.

But what are the consequences? Suppose we took the genealogical chart just quoted, and extended it across the different media (cinema, television, internet), by including the telephone, radar, the computer, and all the other technologies said to be driving these media towards convergence. We would then come to something like the following "canonical" account of the different phases: the early, primitive period (of "living pictures") lasted from 1895 until 1917; the second phase coincided with the "maturity" of silent cinema and lasted to 1927. The third period comprises sound cinema, from 1928 to 1948 . The postwar years to the mid-1960s are dominated by the twin poles of neo-realism and wide-screen colour, after which television takes over as the leading medium. The reign of television lasted until the mid-1980s, since when the digital media have begun to encroach on both cinema and television. Such a neat periodisation sutures a series of clear markers of difference in order to trace a sequence of changes, inscribing themselves in more or less self-evident (though also self-cancelling) teleologies: those of realism, of perfect illusionism, of live-ness and of simultaneity. While this may be the most commonsensical approach to media 
succession and is the one still widely prevailing in survey courses as well as popular publications, its flaws in the eyes of a scholar trained in the New Film History or a media historian are all too evident. The account takes as its main points of reference for plotting "change" either the basic technology (sound, colour, screen format), or economically motivated legislation (e.g. the Paramount decree, or the abolition of the Hays Code, in the case of Hollywood). Added to this: the aesthetic parameter of realism, whose implementation becomes the ever closer, yet also constantly receding, telos of moving image history. But if one were to spell out the technologies involved, one would immediately note a radical discontinuity. For instance, the first, cinematic apparatus is made up by the projected moving image fixed on celluloid, and subsequently synchronised by optical sound. The second, televisual apparatus is an illuminated screen attached to a cathode ray tube. The third, electronic apparatus focuses on the digitised transmission of the audio- and visual signal, processed by a computer and reproduced on a monitor via external or built-in storage devices such as zip-drives, CDROM, DVD, or an internally accessed server, on-line with the world wide web. The telos turns out to need a set of moveable goalposts, chasing the chimera of what-realism? instant communication? virtual reality?

In other words, not only the chronological stories of successive technologies or devices but also the genealogical charts quickly come to a conceptual dead-end. They take little account of the very different institutional histories of the media that arose around these technologies, their uses or implementations: the film industry, radio, television, the internet all have distinct institutional, legal and economic histories. Genealogies may register but cannot explain key similarities of "content" across these media. For instance, the persistence of the full-length feature fiction film, which is the basic commodity of the film industry but also serves as the standard currency of television programming and domestic media use, is implied but not named. Nor does such a chart illuminate the vexed question of "classical" cinema already alluded to: its consolidation around 1917 (not a technological point of change or rupture) and its demise or 
transformation in the 1960s (determined, by common consent, through economic and institutional changes). Moreover, both the succession model and the expanded chart relegate film to the margins and make it a thing of the past, which contradicts the internalised ubiquity of the "cinema-effect" mentioned at the beginning. But it also underestimates the cinema's continuing economic significance as a generator of (cultural) capital, where festivals and first releases secure intense media attention and star-status for a relatively small number of films, directors and actors.

Yet there are also problems the New Film History finds hard to tackle, once it steps outside its preferred terrain of early cinema. So far, for instance, "revisionist" film historians have not been very successful at picturing the relation between the different stages of film form (editing, montage, close-up, insert-shots, deep staging, framing) and film style (all we have are successive movements, cycles of genres, formally defined -isms). Or how can we account for cross-media configurations (adapting or repurposing the same "content" or stories in different periods or for different media), and how explain the coexistence, the overlap and sometimes interference among historically successive or wholly different technologies? Causal models, problem-solving routines or even evolutionary explanations are of little help. Cinema did not relate to the magic lantern in strictly causal terms nor did it "respond" to it by solving problems that had arisen in the practice of magic lantern shows. It re-purposed aspects of magic lantern technology and parasitically occupied part of its public sphere. Television has not "evolved" out of cinema nor did it replace cinema. Digital images were not something the film industry was waiting for, in order to overcome any felt "deficiencies" in its production of special effects. Likewise, the coming of sound in the late 1920s and throughout the 1930s still poses major problems of how to factor in the "media-interference" from radio and the co-presence or competition of the gramophone industry. The same goes for the history of television in the 1950 s and its relation to radio, to canned theatre or to the more avant-garde or experimental uses of video. In all these cases, the methods of early cinema have yet to 
prove themselves as decisive conceptual tools of either historical explanation or informed prediction (with regards to convergence versus self-differentiation, for instance). What help can archivists expect from the New Film History when trying to deal with their non-fiction holdings, with industrial, educational or advertising films? And when will we have theoretically informed accounts of all the (other) non-entertainment uses of moving image technologies? To deal adequately with these issues, the New Film History may have to break with its cyclical models as well as with its genealogical ones. Especially when genealogies simply become ways of waiting for the "next big thing" to be declared the implied goal, so that selectively chosen predecessors can then be seen to lead up to just this point. We now have several perfectly plausible accounts of how instant transmission, media networks, and even the internet have always already been just what humankind was waiting for. And the wonderfully rich recovery work done by historians on stereoscopy, phantom rides, Hales Tours, dioramas, world exhibitions, wax museums, stuffed animals, natural history habitats or David Belasco-type complexly engineered theatrical spectacles courts similar historiographical objections. Wherever the New Film History charts its longue durée accounts around "multimedial," "immersive," "panoramic" or "haptic" media experiences, it also serves to legitimate a covert but speculative and, in all likelihood, transitory teleology.

Such caution may seem ungenerous. After all, these perspective shifts have been salutary: they continue to be immensely valuable in producing new knowledge in the best historicist tradition. They add unexpected genealogies to our contemporary visual culture and serve to defamiliarise the cinema, and thus to refresh our awareness of it. They can put in crisis habitual classifications and categories, such as text, work or author, rather than put the digital forward as a surreptitious (and even more deterministic) new teleology. Studies such as those devoted to the history of movie-houses and exhibition practices reaffirm the specific history of cinema. They once more privilege the film theatre and the big screen as the normative reception context, as if to counter the urban ubiquity of the cinema experi- 
ence, and the fact that we are more likely to encounter moving images on monitors and television screens. It points to another paradox, namely that the immersive and transparent experience of the contemporary multiplex screen exists side by side with its apparent opposite: the multi-screen hyper-mediated experience of television and the billboard-and-poster cityscape. On the one hand, "virtual reality," on the other, the web-site or the computer's "windows" environment. Can we explain both as versions of the "cinema of attractions," without evacuating the concept?

At the same time, the question of realism has not gone away. Although the prevalence of fantasy genres may prove just how untenable the grand narrative of the cinema's traditional telos of greater and greater realism is, why should fantasy have become the preferred mode since the 1980s? Surely not because "realism" is taken care of by television, whose images are increasingly broken up into multi-mini-screens and a moving frieze of text and figures. The classic evolutionary scheme from silent to sound, from black and white to colour, from the flat, twodimensional surface to 3-D, from the peephole kinetoscope to the IMAX-screen not only does not hold up. We can see how much of it was underpinned by certain definitions of realism, as a technology of panoramic, total perception and transparency. Realism's invisible underside, so to speak, has been surveillance. The panoptic gaze highlights a key differentiation of cinema history as an apparatus history, often neglected when discussing the realism effect as a subject effect: that between private and public. To the extent that this divide today is threatened, if it has not already collapsed, the distinction becomes relevant also for theory. The separation of cinematic realism from the correspondence theory of truth (anchored in the so-called "indexicality" of the photographic image) and its redefinition within a coherence theory of truth (based on trust, belief and shared conventions) makes more urgent a clarification of what we mean by reference, authenticity and transparency. Once more, the digital plays an odd role in this: it did not cause the rise of the surveillance paradigm, but it certainly made it more "visible," retrospectively proving that in its "invisibility" it had been there all along. If the arrival of the digital pixel "created" the concept of 
the post-photographic image, the consequence was that it also changed the meaning of photographic realism. ${ }^{13}$ Such semantic shifts-a sort of constitutive inversion of cause and effect-are well known in media history: black-and-white was an "effect" of the introduction of colour, just as the arrival of the compact disk (after the audio-tape) revived interest in gramophone disks and created the concept of "vinyl." Seen from the perspective of this type of Nachträglichkeit, i.e. retroactive causality, Louis Lumière and Andy Warhol have more in common with each other than they have with Georges Méliès and Stan Brakhage. But this is because our present interest in the storage and indexing of time has re-shuffled the categories of documentary, avantgarde and fiction, seemingly keeping in place and yet also making obsolete such traditional divides as that between "realism" versus "fantasy."

Questions such as these encourage film historians trained in the field of early cinema to look beyond the boundaries and extend their competence more generally. For example, early cinema has taught us to think of film history no longer as a collection of masterpieces, but to look for normative practices, epistemic breaks, symbolic forms or distinct modes. Nor do we continue to regard filmmakers as participants in some transnational baton relay race, where the inventor, pioneer or genius passes on the art of cinema from one generation to the next. Rather, the whole balance sheet of "winners" and "losers" is constantly revised-retrospectively, with "undeservedly neglected" figures being "rediscovered" all the time. The electronic and digital media provide a similarly corrective reference point to the notion of "author" and "work": their products are often presented as "worlds," even more than as stories, and as audiovisual events, rather than as single "works." As a consequence, new distinctions arise that in turn have repercussions on how we view the cinema. Films now tend to be part of a culture of "experiences" and an economy of spectacle, where neither individual authors nor individual films are placed at the centre. But this does not mean that there are no iconic figures, such as Steven Spielberg and George Lucas, or retrofitted auteurs, like Quentin Tarantino or Lars van Trier. However, not even for these undis- 
puted creators of personal works is "self-expression" the chief indicator of authorship. Instead of playing the auteur off against "the system" (as was claimed by the auteurists of Cabiers $d u$ cinéma), the auteur now is the system. Directors have become small-scale or large-scale entrepreneurs, image-engineers of films as "multi-media" concepts and total environments, with auteurist oeuvres replaced by fantasy worlds and cosmologies (Star Wars, Lord of the Rings, Kill Bill). On the other hand, almost the same films (say, Hitchcock's) that have become part of the world repertoire of cultural commonplaces are also entering the museum, where they are performed, sampled and displayed with the full aura of the auteur-artist reinstated.

Some of this may apply to what Lev Manovich once said about "theory": that it is the funeral of a practice. ${ }^{14}$ Will it come to be said of film history that it is the (retroactive) resurrection of collapsed distinctions? We care about the indexicality of the photograph because we miss it in the post-photographic pixel. We celebrate the "materiality" of clunky 18 th century stage machinery or the elaborate illusionism of a Pepper's Ghost phantasmagoria because of the effortless creation of such threedimensional "special effects" in computer graphics virtual space. We marvel at the sheer "diversity" of 19th century visual culture-maybe because we sense its imminent disappearance? In which case, "convergence" might be less our inescapable fate than the name of our inadmissible fear, nostalgically but also frantically driving our excavation and preservation efforts.

\section{Media Archaeology II: Family Tree or Family Resemblance?}

How can we begin to "think" such a changing media-landscape, and what implications does it have for our idea of placing film history within the "expanded field" of media-practice? The New Film History has taken initial steps in this direction, insofar as it deliberately eschews focusing on the "origin" of a praxis or refuses to be excited by who was the "first" to use such and such a device or technique. This procedure is inspired by Michel Foucault, who in his essay "Nietzsche, Genealogy, History" warned the reader to identify Nietzsche's notion of "descent" with "origins" or "inheritance." Neither should one confuse 
genealogy with the search or tracing back in time of an unbroken lineage. On the contrary:

[...] an examination of descent permits the discovery, under the unique aspect of a trait or a concept of the myriad events through which-thanks to which, against which - they were formed. Genealogy's... duty is not to demonstrate that the past actively exists in the present, that it continues secretly to animate the present, having imposed a predetermined form to all its vicissitudes (Foucault 1977, p. 146).

Practically, this means considering the history of image and sound technologies as made up less of a family tree and more of "family relations"-belonging together, but neither causally or teleologically related to each other. Almost all "from... to" histories have been, as we now realise, in one way or another deeply flawed. In fact, they seem factually so inaccurate as to make one wonder what kind of intellectual sleight of hand or acts of self-censorship must have taken place for so much knowledge about early cinema and so many discourses about colour, sound and the many experiments with giants screens or 3-D glasses to have been "forgotten."

Thus, a real challenge even for the genealogical approach is our lack of knowledge about the many interconnections-but even more so, about the gaps-between the media. No medium replaces another, or simply supersedes the previous one. ${ }^{15}$ Today, cinema, television and digital media exist side by side, feeding off each other and interdependent, to be sure, but also still clearly distinct and even hierarchically placed in terms of cultural prestige, economic function and spectatorial pleasures. The question is: how can we describe or analyse these mutual links, while also marking the spaces that distinguish the media, without falling back into writing their "separate" histories?

A possible approach would be that of "system theory," which assumes that instead of the different media, say of cinema, television, internet, heading towards convergence, they are moving towards greater differentiation in both their (pragmatic) uses and their underlying relation to each other. ${ }^{16}$ Again, early cinema studies has shown the way. The film strip's antecedents are, 
on the one side of the "family," the industrial production of cellulose sheets (as opposed to the hand-made glass plates of early photography), but also chronophotography, made possible by "fast" emulsions (such as Louis Lumière's famous étiquette bleue). Yet chronophotography is not cinema: it needed flickerfree projection secured by the mechanical intermittence device that we know as the Maltese cross. This opens up the other side of the family, leading to the screen arts of projection, themselves as different as magic lantern slides, fog pictures and phantasmagorias. Our two parental genealogies, however, leave out a third, constituting on the exhibition side the very conditions of the cinema as public performance and entertainment form, namely the history of music hall, vaudeville and the variety theatre.

Sound cinema has, as one of its "parents" the experiments in synchronisation that run parallel to the history of cinema right from its beginnings, with Edison having, as we know, conceived of his kinetoscope as an illustrating device to complement his phonograph (whether these experiments were in each case successful or not is of secondary importance). On the other side of the genealogical tree, sound cinema has to do with the development of the gramophone as a prime domestic leisure commodity, and the popular appeal of radio in the 1920s. ${ }^{17}$ The first successful sound pictures all featured hit songs also marketed as records, and played on the radio. At the more directly industrial and economic level, the rapid development of sound equipment and the sound film's almost instantaneous introduction internationally refers us directly to the power-struggles and patent wars of the major multinational electricity companies, such as Westinghouse, General Electric, Siemens, AEG.

Radio is also a key parent in the history of television, since the scarcity of airwaves as well as the size of the infrastructural investment made television in most countries, and for most of its history, a state controlled monopoly, whose institutional structure had everything to do with national broadcasting corporations and little to do with the film industry until the 1970s. Even in the United States, the history of (commercial) television and the history of the cinema began to dovetail significantly 
only in the mid-1960s and then again in the wake of the major take-over and merger wave of the 1970s.

The cathode ray tube and its ability to transmit images was "discovered" at about the same time as the cinema, and thus cannot be said to be a "successor" to the photographic process: it is quite simply an alternative technology, engaged in transmission rather than storage, valorising instantaneity rather than permanence, and putting a premium on simultaneity and "liveness" rather than realism and illusionist presence.

At the limit and if pressed, one could perhaps name the phenakistoscope-understood genealogically, rather than causally - as the common ancestor of both cinema and television, insofar as the optical slit of Plateau's device is not only repeated in the keyhole principle of Edison's kinetoscope, and then "translated" into the Maltese cross of the projector, but it also "anticipates" the rotation of Nipkow-disk, a distant precursor of television. Put differently: cinema and television have at one and the same time absolutely nothing in common and yet are closely related to each other. Only because television has in some respects "taken over" and established itself as the priority medium can we now recognise that the phenakistoscope offers itself as the joint ancestor of both. This would be a case of a genealogical demonstration after the fact, rather than a chronological-causal "explanation."

Is the question of family relations, networks and synergies always as fragile as this? Film scholars such as Ann Friedberg have rightly pointed out that certain audio-visual technologies (notably the video recorder and cable television) began to challenge the differences between the cinema and television at a time when personal computers, fibre-glass optics or digital images had not yet been introduced. ${ }^{18}$ If, for instance, one were to argue (as scholars did in the 1970s) that a key distinguishing trait between cinema and television was the fact that the latter was "live," this difference seemed to be eroded with the arrival of the video recorder, which — with its ability to store timealso undermined another distinctive feature of television, the "schedule" and the monopoly of programming the nation's daily attention. One might say that the "invention" of CNN was tele- 
vision's counter-move to the VCR, trying to recover live-ness and the event though "covering" the "stories" of the world as they "break." Yet what brings cable-TV and the video-recorder close to the cinema is the large "archive" of readily available movies. Here the VCR leapfrogs the cinema, in that the choice and selection become at once customised and arbitrary. It emancipates itself from the schedule, a feature that the cinema and "live" television used to have in common. Did not the battle between VHS and Betamax prove that the video-recorder began its entry into the world's living rooms mainly as a playback machine and not as an off-air recording apparatus? What family resemblance there was between cinema and television was thus a consequence of an adjustment of the spectator's field of vision to the television screen as the default value. Or put more generally, a new definition emerged of the idea of the "window," which already hints at the metaphoric slippage that occurred from film screen towards the computer monitor and its multimedia applications, part of the blurring of the distinction between viewer, participant and user. ${ }^{19}$

The remote control may have changed the structure of television programming even more decisively than cable and the VCR, affecting the genres, the pace and the mode of address of television, while also making its impact on film form, as we shall see. Cable and satellite reception also managed to break up the institutional arrangement of television, especially in Europe, by not only extending the overall amount of choice, but by taking control over this choice increasingly out of the hands and guidelines of governments, which until then had largely policed access. This push in the direction of commercial criteria for choice and selection brings television once more closer to the cinema and already points in the direction of the internet.

From such an incomplete sketch one can at least deduce that it was a whole range of very different technologies at different points in time, with very different agendas, which have contributed to changing our idea of the audio-visual media and their respective relation of medium-specificity and multi-mediality. It also shows how many battles, conflicts and unresolved incompatibilities run alongside any narrative of media-networks 
or system-synergies. What we can note instead of convergence is a slightly different phenomenon. Since the time portable videoequipment became professionally available towards the middle of the 1960s, each decade appears to have produced a kind of prototype. It not only dominated the market in its field and captured the imagination of the mass consumer, but often initiated a new cultural configuration - an episteme-as well, by promising novel uses and leading to changes in life-style and leisure. Thus, while not belonging to the "digital revolution," the video recorder and the remote control have helped to alter irrevocably both structure and uses of television, as well as our notion of what watching movies at home would mean. The DVD has technologically improved this experience, but can it be said to have added a cultural transformation? Undeniably, the DVD (with its bonus packages and audio-commentary) is reshaping our film culture and thus our film history, while also initiating new debates about originality (the director's cut), authenticity (digital remastering), and the relation between text and context ("the making of" materials).

The video recorder never laid claim to authenticity, but it permanently affected our relation to time. With it, time could be stored, reversed and shifted, which means it became available for other types of measurement, for other kinds of experienceto the point of becoming interactive, establishing a temporal regime that was parallel and virtual, just as it was "real time" and actual (and this, again, well before the signal or the device became "digital"). The video recorder's most prominent use now is in surveillance, as the medium for measuring "empty time." Ten years later, it was the portable personal stereo, better known as the Walkman, that reconfigured the experience of space and subjectivity, and established a different ratio between private and public, between motion and emotion.

The mobile phone, of which the Walkman can in some sense be seen as the precursor (but certainly not a 'parent'), has given a further incremental twist to our notions of time and space, of interactivity and mobility. These technologies, so seemingly remote from the film experience and the cinema, nonetheless appear to have modified our ideas of spectatorship and partici- 
pation with respect to the traditional cinematic medium. One can begin to speculate what the common denominators between these devices are-ease of access, instantaneity, mobility, the combination of personal intimacy and public space, etc. Nonetheless, it is obvious, once one takes such a long view, that digitisation-the usual denominator, in the name of which convergence is assumed to be inevitable-while it has its part to play, is not the only motor of these changes. "Digital media" are, furthermore, themselves hybrid phenomena, when looked at genealogically. The technologies they rely on also have at first glance little to do with the cinema: the computer was developed for military purposes in order to help break the codes and intercept the messages of Nazi-Germany's "Enigma" machines. The modern monitor screen with its "interactive" potential equally belongs to the sphere of the military and has as its predecessor the radar screen, first devised for scanning the skies and tracking enemy aircraft. Digital media are also associated with the military via the development of the internet, which relies on the telephone and its extensive and intricate web of world-wide connections. These in turn are supported by satellites orbiting the earth, again a development referring us both to the Cold War and to the fact that advances in audio-visual technology for the entertainment business invariably represent spin-offs or bastard children of military aims and priorities.

In other words, if a genealogical model of film history, whether straightforwardly linear or pictured as a more complexly branching family tree, lands us with far too many black sheep cousins, promiscuous parents or profligate grandparents to create a credible line of descent, the "rupture" represented by the digital will oblige us to break with the genealogical model as well as the chronological. Hence my insistence that digitisation be treated not only as a new technical standard (which it undoubtedly is), but that it also names the situation which I hinted at in the beginning. We seem to be on an inside for which there is no clear outside, and we seem to be in a "now" for which there is no clear "before" or "after." Thus, the move to the digital marks a threshold and a boundary, without thereby defining either. A radicalised version of the genealogical way of 
thinking would lead us, in other words, to a properly "archaeological" perspective, where no continuity is implied or assumed. The past is recognised as at once irrecoverably "other" and separate from us, and it can be seized only by a hermeneutics of the fragment, a discourse of metonymies, and an "allegorical" view of (always already lost) totalities.

The project of a "film history as media archaeology" is thus intended to liberate from their straight-jackets all those re-positionings of linear chronology that operate with hard binaries between, for instance, early cinema and classical cinema, spectacle versus narrative, linear narrative versus interactivity. Instead, film history would acknowledge its peculiar status, and become a matter of tracing paths or laying tracks leading from the respective "now" to different pasts, in modalities that accommodate continuities as well as ruptures. We would then be mapping media-convergence and self-differentiation not in terms of either a teleology or a search for origins, but in the form of forking paths of possibility, i.e. as a determined plurality and a permanent virtuality. For such a programme, the current confusion around New Media provides a refreshingly provocative opportunity. ${ }^{20}$

\section{Media Archaeology III: What is Cinema or When is Cinema?}

Thus, given the problematic status of all media genealogies, one has to conclude that even the efforts of the New Film History to rethink the cinema and its history as a whole have been partial, and in any case present us with an incomplete project. ${ }^{21}$ The provisional and variable nature of the pre-cinematic pleasures and attractions (the already mentioned dioramas and panoramas, Hale's Tours and phantom rides, haptic-tactile images and bodily sensations) make it evident how much the cinema, even after more than a hundred years, is still in permanent flux and becoming. Or, again put differently: given the cinema's opportunistic adaptation to all manner of adjacent or related media, it has always been fully "grown up" and complete in itself. At the same time, it has yet to be "invented," if one is looking for a single ancestor or wonders about its purpose in human "evolution"—as André Bazin, who left us with the 
question "what is cinema" and himself speculated on its "ontology," knew only too well. ${ }^{22}$

This is why the example of early cinema suggests a "systems" approach (of self-differentiation), rather than a linear dynamic (the argument from convergence obviously lets linear history in through the back door), or even the sort of dialectic of binary oppositions by which the "cinema of attractions" is sometimes described. The "unfinished" nature of both the cinema and the efforts to write its histories help to highlight one of the drawbacks of this seminal concept-its interpretation as a cyclical trope of "return"-which in recent film historical work has functioned as a template determining the object of study as well as serving as an explanatory method. However didactically stimulating it is to find historical parallels to our own preoccupations and obsessions, the illuminating effect may have to be paid for by tautology and circular reasoning.

To mention one instance: the notion that the cinema of attractions can explain post-classical cinema distorts both early cinema and post-classical cinema. Other attempts have been made to explain the features said to be typical of the cinema of attractions in the early period. I am thinking of Charles Musser and Corinna Müller's arguments that the life-cycle of short films and the numbers principle (modelled after variety acts) as a programming and exhibition practice in early cinema can best be understood in terms of a set of economic parameters obtaining in the latter part of the first decade of the 20th century. ${ }^{23}$ The disappearance of "editorial control" and of variety act programming around 1909-1912 in favour of the longer film would then have to be directly correlated to the conditions necessary to establish the film business as an industry, among which "narrative integration" might be one way of providing a functional equivalent to the numbers principle. Gunning's binary formula, strictly applied, would screen out the industrial-institutional context that gives his formal distinctions their reality and historical ground. ${ }^{24}$

Likewise, there are other models of how to explain post-classical cinema, if we admit that there is such a thing: for instance, the revival of a numbers principle in modern action cinema has 
more to do with the fact that a feature film is made today with a view to its secondary uses on television. Television, at least in the US context (but increasingly also in the rest of the world) means commercial breaks during the broadcast of a feature film. The "return of the numbers principle" is thus a direct consequence of the cinema adapting to its television uses, rather than its inherent affinity with early cinema. In other words, too easy an analogy between "early" and "post-classical" cinema sacrifices historical distinctions in favour of polemical intent, too keen perhaps to squeeze the hegemony of the classical cinema in a sort of pincer movement at either end of a hundred year continuum.

As presently employed, the notion of a recurrent, or even dominant, "cinema of attractions" is thus perhaps both too polemical and yet not radical enough, if one really wants to break with the dominance of "narrative integration" and the classical cinema. A more thoroughgoing revisionism would have as its aim to once more re-assess the relation of the cinema-all cinema, including digital cinema and the electronic media-to diegesis, narrative and narration. For these are the main parameters that constitute the cinema's textual and ideological functioning, and they also regulate how a spectator is addressed as both (imaginary) subject and physical, embodied presence in a determinate space. Paradoxically, after what has just been said about works and texts, these different tendencies toward providing images and sounds with some "diegetic" ground-different in early cinema, in classical cinema and in the new media objects - can best be studied, in their temporal and spatial coordinates, via close attention to individual films or to a particular "corpus." Gunning himself has done so, and has robustly defended close textual analysis, and so have others: Yuri Tsivian, Ben Brewster, Kristin Thompson. I, too, have looked at films from the teens and early twenties by D.W. Griffith, Franz Hofer, Joe May and Fritz Lang with the question "when is cinema" in mind. Especially the period of the teens is emerging as rich in materials for a new concept of diegesis in relation to narration and commentary, to screen space and auditorium space, but also in relation to display and mise-en-abyme. These last 
two characteristics of the "cinema of attractions" have hitherto been constructed in opposition to narrative, partly, I suspect, for lack of an appropriate concept of diegesis, or "world-making." ${ }^{25}$ In all these cases of early cinema practice, narrative integration is a process taking place between screen and audience. These interact at all times and cannot be rigorously separated from each other, as is the case if the oppositional pair of cinema of attractions versus cinema of narrative integration is to be maintained. And just as the shifting parameters of screen space and audience space help redefine the "world-making" of early cine$\mathrm{ma}$, while the relations of diegetic, extra-diegetic and "imagined" sound offer new insights into the films especially of the early sound era, so parameters like fixed spectator/mobile view, mobile spectator/fixed view (and their possible permutations) are important clues to the embodied or site-specific "diegetic reality" of video-installations and digital art.

The question, then, is not so much: on one side spectacle, on the other narrative. Rather: we need to ask how the cinema established itself as a symbolic form to such a degree that the event character of the film performance (one meaning of "the cinema of attractions") was able to enter into a seemingly natural union with linear, causally motivated, character centred narrative? This raises a counter-question, from the perspective of cinema as event and experience: under what conditions (be they cultural-historical and/or technological-industrial) is it conceivable that the moving image no longer requires as its main support the particular form of time/space/agency we know as classical narrative, yet still establishes a coherent "world?" Are other kinds of diegesis conceivable that similarly accommodate the spectatorial "body" and give the impression of "presence?" What forms of indexicality or iconicity are necessary in order to accept other combinations of sounds and images as relating to a "me"-as subject, observer, spectator, user? The answer might be "virtual reality," "interactivity," "immersivity." But are these not mere attempts at re-labelling the question of cinematic diegesis - with the possible disadvantage of being too focused on the single individual, and giving priority to only one of the cinema's effects, that of "presence," understood as "real-time?" It is 
thus the question of diegesis (as the combination of place, space, time and subject) more than the issue of digitisation that requires us to redefine the very "ground" of the moving image in its multiple sites. Media archaeology takes a first step in this direction, since it would try to identify the conditions of possibility of cinema ("when is cinema") alongside its ontology ("what is cinema").

While initially, one might say, scholars of early cinema had to become archaeologists, if only because of the sheer number of incoherencies, inconsistencies and errors in the traditional accounts, which could not be rectified simply by adding more "facts," film historians today should remain media archaeologists for a variety of reasons. Take, for instance, archival policy and preservation practice of the past twenty years. Just as in historical archaeology, where one finds a split between those digging for art-works, treasures and "gold," and those making straight for the rubbish tips and fireplaces of lost civilisations, so there is a split between film archivists. There are those who are above all interested in restoring "masterpieces" which can be "rediscovered" at festivals, shown during retrospectives and celebrated in handsome publications, and those archivists who are more concerned with cataloguing, interpreting and thus rescuing the "bits-and-pieces" of their collection. Adding value, by calling them the "orphans of the cinema," they study what was once thought the detritus of film culture and the cinematic heritage, in order, for instance, to focus on what can be learned from "programming." Some are interested in dating the consolidation of historical "norms" and identifying studio-styles of setdesigns, camera placement and figure blocking, and others still are mining advertising, industrial, educational or medical films for the information and data they provide.

History as archaeology adds to this a further insight: it knows and acknowledges that only a presumption of discontinuity (in Foucault's terms, the positing of epistemic breaks) and of fragmentation (the rhetorical figure of the synecdoche or the pars pro toto) can give the present access to the past, which is always no more than a past (among many actual or possible ones), since for the archaeologist, the past can be present to the present 
with no more than its relics. Finally, an archaeology respects the possible distance the past has from our present perspective, and even makes it the basis of its methodology. Nonetheless, positing breaks too quickly as 'epistemic' invites the charge of formalism. A more rigorous media archaeologist's point of view would assume that the breaks point to gaps in our knowledge, though one would be careful not simply to fill in the blanks with new "facts" before considering that a "missing link" may well have its own meaning —as a gap.

\section{Media Archaeology as Memory Art and World Making}

Chronology, genealogy, opposition, alternation-these are some of the modes of temporal sequence and causal disposition by which historians make sense of the continuities and ruptures, the lines of force and the piles of fragments in the records of human actions and events. The same goes for film historians faced with the family of media that rely on the moving image. Trying to make sense of the elements of specificity and interdependence, noting overlaps and functional equivalences, and interpreting moments of competition, influence or emulation as signs of convergence and synergy, they have usually opted for a chronological, a dialectical or a genealogical approach. To these I suggest adding an archaeological "turn" in order to describe the emergence and development of cinema, not in its own terms or when competing with television, but within the technical and electronic media of the 20th century generally. I take my cue from Foucault, who had already recommended that the genealogical method should break with the conventional nexus of causality, but who also cautions about understanding genealogy as a lineage that can trace the present back to its "beginnings." Where Foucault separates cause from effect in order to re-articulate the lines of force of his chosen field as an archaeology of discourses and practices, the model of media-archaeology that I am proposing involves two stages, one historiographic, the other ontological. This archaeology, too, knows no "beginnings," and does not make a division between the history and prehistory of the cinema. But neither does it hold the histories of the moving image, the photographic and post-photographic 
image or the panoramic view, suspended in a purely conceptual space, ready to be re-arranged by the different discourses of power and knowledge. It also feels no need to re-integrate the disparate parts from the point of view of the present, with or without teleological inevitability, with or without leaving room for the virtual next to the actual. ${ }^{26}$

What, then, are its features, and how are these related to the idea of a two stage approach? Taking the historiographical stage first: it will be recalled that the problem a film history conceived as media archaeology is meant to address is not only the incoherence of certain historical accounts of how the different media of the moving image relate to the cinema. The problem is also how the "revisionist" picture of the many alternative histories and parallel genealogies, which I briefly outlined, can be made pertinent to the specific question posed initially. What can early cinema studies tell us about the kinds of rupture represented by the digital, and thus what does it teach us about our present multimedial, intermedial, hypermedial moment? If the "digital media" are a taxing test for film history, I argued, it was because they oblige us to extend the archaeological approach to include the present, rather than give the present the hindsight (ad)vantage on the past. The challenge thus lies in finding a place that is not fixed in respect to either position or direction, one that permits spaces to coexist and time frames to overlap. This place, I also suggested, can only be an enunciative one, in which the present features not in relation to the past or future, but as the "I" and "you," the "here" and "now" of discourse. Discourse is here understood in Emile Benveniste's sense of being crucially constituted by these shifters and deictic marks just mentioned, whose characteristic is to be at once universal in their use and unique in their reference, but in each case requiring additional specifications of time, place and self, provided by the speaker's presence. The enunciative act, in other words, is always a function of making explicit the implicit reference points, the self-reference (deictics), the data or evidence, on which the speaking position, and thus the meaning of an utterance, depend.

But such an enunciative position within discourse identifies an "empty" place, activated only when filled by a presence. The 
place-holders of this presence vary, determined by the discourse they help bring to life. If the Freudian unconscious was such a place-holder in the enunciative theories of psychosemiotics, a case in point today would be the discourse of "cultural memory." There, "history" intersects with retrieval, collection and recollection, to produce the enunciative position of personal memory, testimony or even trauma. Indeed, the kinds of selectivity of evidence, the processes of remembering and forgetting, of retrospective re-writing and retroactive causality which I have been discussing as typical of the New Film History, in both its aporias (from the historiographic perspective) and its achievements (from the media-archaeological perspective), are also a fair description of what we understand by "personal memory." Is the loss of one (the "objectivity" of history) always the gain of the other (the "authenticity" of memory)? Memory is an awareness of the past, in which the data is continually re-organised and sorted, according to new priorities and thus also new categories. In the case of an individual, memory is the locus of personhood, assuring a sense of identity across the discontinuity of lived moments in time. By contrast, collective or public memory has always been a contested territory of rival claims. There, not only the narratives of history are re-written to suit the present. Power-relations, too, are being re-negotiated, continually raising questions of appropriation and expropriation around the stakes of recognition and legitimacy. To slightly vary a line from Walter Benjamin: if history is indeed written by the victors, collective memory has often been regarded-notably also by Foucault-as necessary acts of resistance to this history.

Into this division between history and memory, the audiovisual media have introduced a further dimension, in one sense mitigating or even bridging the divide, but in another sense aggravating the opposition. Never in the history of humankind has there been such an extensive, exhaustive, instantaneous and immediate storage medium as the moving image for the inscription of human actions and events. Yet in spite of having now been in existence for more than a hundred years, the cinema has been eyed with extreme suspicion by those institutionally in charge of public records and official memory, namely archivists 
and historians. They have never accepted even so-called "documentary film" (never mind the feature film) as a source of evidence for the historical record. This suspicion has only increased with our entry into the post-photographic age and the arrival of digital images, though one could argue that this is a rationalisation after the fact, since the distrust has been there since the beginnings, even if, in each epoch, it is being argued on different grounds.

In this sense, the cinema seems to have aggravated the split, suggesting that moving pictures (despite the fact that as part of mechanical memory they are also a pure storage device, where everything is recorded, for future retrieval, sorting, manipulation and access) belong to the category of human memory, and thus always require an enunciative act in order to be intelligible. For phenomenologists and realists, such as Henri Bergson, Siegfried Kracauer, André Bazin or Gilles Deleuze, this argument is strengthened when considering that many formal or stylistic devices of the cinema-from flashback and superimposition to editing and close-up-have a remarkable affinity even to some of the empirically verifiable properties of visual memory. In addition, the reason why people allow their own memories to be overwritten by photographs and moving images (seeing them often as more "accurate" or more "vivid" versions of their own perceptions and recollections) lies precisely in this natural affinity between photography and memory, and in an uncanny ability of cinema to mimic or "model" certain processes of human consciousness, of the unconscious and of memory.

But if I am right about the presence of the "cinema in our heads" and about the ubiquity of the electronic media in our everyday environment, there has been a blurring of the boundaries between public and private, between individual testimony and collective experience. This further complicates maintaining any categorical distinction between "history" and "memory," and to this extent, mediatised versions of history on television and in the cinema have also mitigated the split. The data available though the cinema corresponds much more to the active, evolving and incessantly worked-upon concept of memory, where the information-richness of the moving image, the 
resources of visual rhetoric and of narrative, the filmic modes of enunciation and address, of focalisation and identification, are shaping memory in a way that is perceived as both more relevant to individuals (and more empowering to groups) than official history: because its active, affective nature appears more authentic and closer to lived experience. Perhaps as a consequence, displays of personal memory and public commemoration-now so often in the presence of the media-have become touchstones of authenticity, giving the act of testimony and recollection (especially when embodied in the witness as privileged model or form of spectatorship) a new kind of legitimacy.

At the same time, such bottom-up authenticity cannot but be unsettling to institutions and their gatekeepers, because of the technical malleability of the source material and the suggestibility of subjective memory through the filmed images and photographic records. The historian's distrust-well-founded in his or her mind by the fact that testimony from eye-witnesses is unreliable at the best of times and can so easily be interfered with by images they may have been exposed to subsequently-is thus the acknowledgement of an implicit struggle. This contest is between two kinds of recording-system (the human mind and psyche on the one hand, the camera and sensor on the other), whose data in each case are treated by the historian as (raw) material or information, rather than as documents or embodied action.

In order to resolve this issue, or at least to focus on it more firmly, media archaeology requires a second step-what I have called the "ontological" one, regarding both the spectators' particular "being-in-the world," and the status of the moving images as "world-making." Earlier on, I discussed this under the heading of "diegesis," the form of space/time/agency/subject articulation, which ensures that the flow of images-irrespective of genre (thriller/musical), style (montage/continuity editing) or mode (documentary/fiction) - is perceived as constituting a "world." At that point in the argument, I wanted the reference to diegesis to overcome several kinds of dichotomies: the one between documentary and fantasy as well as realism and illusionism, but also the one between the "cinema of attractions" 
and the "cinema of narrative integration." These seem to me to stand in the way rather than help when "revising" film historiography or when determining the place of cinema in the contemporary multi-media landscape. Focusing on one of early cinema's most crucial variables, namely the relation between screen space and auditorium space, I argued that both spaces, taken together in their mutual interdependence, made up early cinema's unique diegetic space. Abstracting somewhat, one can summarise it as follows: each viewing was a distinct performance, the spectators felt themselves directly addressed by the on-screen performer, and the audience was assumed by the film to be present as a collectivity, rather than envisaged as individuals interpellated through imaginary subject positions.

If I am now arguing for an expanded concept of diegesis, it is because I not only want early cinema studies to be able to provide the paradigms for studying the cinema as a whole. I also think these paradigms can become productive for understanding the kinds of interactions (converging or self-differentiating) between old and new media, which digitisation may not have initiated, but which it certainly accelerated. In other words, in order to make headway with the idea of "cinema as event and experience" (next to films as works and texts), we need to find a term that allows for the conjunction of the variables of time/ space/place/agency that is explicit in the use of diegesis. It also needs to encompass the deictic markers that are implicit in the term discourse, as defined above, and not exclusive to cinema. In The Language of New Media, Lev Manovich put forward a different contender for the same role, using the term "interface" to designate the meta-space that enables and regulates the kinds of contact that can be made between audience space and screen space, but also between computer user and software. I have chosen "diegesis" because, unlike Manovich, who looks at the cine$\mathrm{ma}$ from the perspective of digital media, I come to contemporary media practice from the study of cinema, and also because, as I hope to show, the ontological, world-making associations of the term diegesis are relevant to my overall argument. The kinds of changes - architectural, social, economic - that eventually led to the separation of the two types of spaces in early cinema, 
making screen space autonomous, and dividing the audience into individual spectators, would thus be the conditions of possibility of the emergence of classical cinema. In their totality they establish a new diegetic space, with formal, pictorial and narratological consequences. It is this totality I would want to call classical cinema's different "ontology."

How much of a learning process this separating/re-aligning actually involved can be gauged by the "Rube" or "Uncle Josh" films popular in the earlier years of the transition. From the Rube films, which show a character repeatedly making category mistakes about the ontology of the cinematic, filmic and profilmic spaces he finds himself in, one can, however, also argue that early cinema's diegetic space comprised a complex but comprehensible arrangement of time, space, place and diectic markers. Fixed or mobile spectator, continuous or single shot, edited sequence or tableau, the look into the camera or off-frame: all of these parameters are staged as variables in their different permutations. The conclusion I would draw is that the successive phases of the cinema, but also the cinema's relation to other media-forms, such as television, video art and digital media, can be mapped by analysing their different and distinct diegetic worlds, comprising the technical apparatus and mental dispositifs, but also dependent on the temporal, spatial and enunciative locators/activators that together constitute their particular "ontology." For instance, the viewer who has the set on all day to accompany his or her daily routine has activated a different ontology of television than the viewer who sits down to watch a particular programme, lights dimmed and remote control safely out of reach.

Thus, early cinema, classical cinema and digital cinema (to name only these) could be mapped on the matrix of particular processes of "ontologisation." Each mode would be defined by the relation an actual spectator constructs for the images and the apparatus, and the degree to which the images are separated from/indexed for not only their material referents, but also their individual recipients. ${ }^{27}$ Just as in painting one can describe the relation between frescos and easel painting (as a correlation of site, size and spectator, where ease of access, transportability and 
spectatorial freedom of movement in the easel painting compensate for the reduction in size and the loss of site-specific markers of meaning compared to the fresco), so in the history of cinema and in the interaction between the media, a similar set of variables could be established, whose default values are the enunciative markers and spectatorial parameters of an audience imagined as physically present/invisibly present, directly addressed/bound into the fiction, and others I already named under the heading of "diegesis." As we know, the cinema seemed to stabilise around aligning the moving image with the special logic of narrative. But the histories of television and of video installations, among others, indicate that there are other options. For instance, the genres of news, talk-shows or talent contests suggest that television has developed its own forms of diegesis, just as a video installation draws its diegetic world from the museum, and brings this space into crisis (see the recurring debates around the "white cube" threatened by the "black box"). ${ }^{28}$ Independently from the arrival of digital images, the particular temporal and discursive logic we call narrative may turn out to have been only one syntax (among others) that can naturalise these processes of separation and enunciative indexing, of mobility and circulation. In other words, it is now possible to envisage the historical conditions in which other forms of "netting" or "knitting" sounds and images, with other architectures of space and other grammatologies of time, take over the tasks which have been (some would say: efficiently; others have argued: stultifyingly) fulfilled by narrative. The moving image would thus "emancipate" itself from narrative, as it has been claimed by the avant-gardes in the 1960s and 1970s (under the label "structuralist-materialist film") and by the digital media in the 1980s and 1990s (as "interactivity" and "virtual reality"). It would do so, though, in relation to establishing particular forms of time/space/subject worlds, in which the parameters of narrative will surely continue to play their part.

If in the transition from early to classical cinema it was narrative and the logic of implication and inference that "liberated" the image from its "here" and "now" (though not the spectator), then the move from the photographic to the post-photographic 
or digital mode could entail another "liberation," though it might just as well amount to an adjustment of diegetic spaces. Could it be, for instance, that "interface" and "installation" are merely the shorthand terms for subsuming the diegetic space we call narrative under some other form of time/space (dis-)continuum, which spectators encounter or inhabit, adopting different roles or positions: as viewers, users, visitors, witnesses, players and, why not, as Rubes ${ }^{29}$ What, one is then prompted to ask, would be the Rube films of today-or yesterday? Certainly, early work (from the 1960s and 1970s) of Andy Warhol, Dan Graham, Andrew McCall or Malcolm LeGrice amply qualifies, seeing how these artists manage to trap spectators in time-delay mirror mazes and get them caught up in cognitive loops.

The idea that narrative is only one possible organising principle of moving images is reinforced by the present preoccupation with memory and the archive. The archive's different logics of database management, and memory's different architectural ruins of storage or baroque theatres of retrieval, already suggests one kind of post-narrative ontology, while the equally vivid discussions around networks and flows, data-streaming and dataknitting provide the starting points for another. Media archaeology would be the name of a practice that adds to film history and its genealogies a third dimension, that of diegesis and ontology, which is why it is cautious about merely "filling in the blanks": they may simply be the empty enunciative spaces where new (and old) discourses are being (re-)activated as practices. So far no medium has yet wholly replaced its predecessors. Likewise, new techniques do not make older ones disappear. They may, however, modify the cultural and economic context in which they function (for instance, a skill or craft can migrate from the sphere of labour to that of art) and also help establish new diegetic worlds or new media ontologies, as is the case with early—and classical—cinema practices being rediscovered by so many (digital) artists.

Media archaeology is therefore perhaps nothing but the name for the placeless place and timeless time the film historian needs to occupy when trying to articulate, rather than merely accommodate, these several alternative, counterfactual or parallax his- 
tories around which any study of the audio-visual multi-media moving image culture now unfolds. Next to an aesthetics of astonishment for which Tom Gunning once pleaded, ${ }^{30}$ there should also be room for a hermeneutics of astonishment, where besides curiosity and scepticism, wonder and sheer disbelief also serve as the impulses behind historical research, concerning the past as well as the present. Perhaps it is advisable in the case of the cinema and its encounters with television and the digital media to speak not only of a past, a present and a future, but also of an archaeology of possible futures and of the perpetual presence of several pasts?

\section{Universiteit van Amsterdam}

\section{NOTES}

1. See the debate around cultural memory, collective memory, and "prosthetic memory," associated with the re-discovery of the writings of Maurice Halbwachs, the positions taken by Pierre Nora, and more recently by Aledia Assmann's work. In the field of cinema studies, Robert Burgoyne, Alison Landsberg, Marita Sturcken, Susannah Radstone and Laura U Marks have significantly contributed to the media and memory debate. I shall return to the issue, albeit from a different vantage point, in the final section.

2. What could be called the "cinema effect" is one of the many reasons why we cannot go on thinking of film history as the history of films. See the frequent references to the cinema in plays, exhibitions, photography (e.g. Andreas Gursky), as well as the different film genres invoked to describe human accidents (such as Lady Diana's death) or terrorist actions (such as the attacks on the Twin Towers and the Pentagon on 9/11).

3. Walter Benjamin was well aware of the pervasive impact of film as a mode of being, when in "The Work of Art in the Age of Mechanical Reproduction," he quotes the French writer George Duhamel (in Benjamin 1978, p. 238): "I can no longer think what I want to think. My thoughts have been replaced by moving images."

\section{See Gumbrecht 1998 (pp. 411-436).}

5. By "New Film History" I am referring to the intervention of a generation of scholars, beginning with Noël Burch and Barry Salt, and continuing with Charles Musser, Tom Gunning, André Gaudreault, Robert Allen, Kristin Thompson, Stephen Bottomore and many others since. Some of the terms of the debate are set out in my "The New Film History" (Elsaesser 1986), and subsequently in the introductions to the various sections in Early Cinema: Space, Frame, Narrative (Elsaesser 1990).

6. One is reminded of the pre-Raphaelites, their preference for Giotto's complexly spatialized narratives in his frescos at the Arena Chapel in Padua. Coinciding with the rise of photography and antedating Cubism, they used Giotto in order to declare war on the perspectival, theatrical, illusionistic pictorial space of the Renaissance and Baroque. 


\section{See Zielinski 1999.}

8. For the treatment of special effects as "attractions," see Sobchack 1987; Bukatman 1993; Hansen 1993.

9. Although, according to Miriam Hansen, the historical intermezzo of classical cinema also marks the brevity of mass-culture dominance in the visual media, her position on the break-up of the classical is that it makes room for the diversification and globalisation typical of the electronic media. Late cinema thus also means a shift in public spheres and the gender-issue of spectatorship first raised around Early Cinema by Judith Mayne and Hansen herself in Babel \& Babylon (Hansen 1991). My own position is more cautious with regards to calling the classical cinema an intermezzo, certainly when it implies a "return" of early cinema modes. And as laid out below, in the final section, I am more concerned with "worlds" than with public spheres, and with diegesis than with technologies.

10. For an analysis of early disaster films, see Wedel 2002.

11. The best-known and most established festivals of Early cinema are the Giornate del cinema muto at Pordenone/Sacile, and the Cinema ritrovato festival at Bologna, annually since the mid-1980s and 1990s, but there are many other regular or irregular venues now celebrating early or silent cinema.

12. The term "parallax historiography" was coined by Catherine Russell (1999 and 2000).

13. See Buckland 1999.

14. In a conversation with the author, if memory serves me right. If not, I may have to take responsibility for the phrase myself.

15. It may seem as if the silent cinema became obsolete with the coming of sound, but when we think how the silent cinema was rarely silent, then this, too, is in fact no exception to the rule.

16. There has, to my knowledge, never been a thorough application of systems theory to film history, at least not in English. The media historian Lorenz Engell has referred himself specifically to Nicholas Luhmann (see Engell 1992).

17. For an excellent account of the respective social impact of new technologies, notably radio, see Boddy 2004.

18. The case for convergence is made by Anne Friedberg (2000).

19. Anne Friedberg's ongoing research into the concept of the "window," first begun in "A Properly Adjusted Window" (1990) and continued in Window Shopping (1993), is relevant here.

20. The opportunities are not only a challenge for scholars and theorists: "Every day we read that the internet economy has burst like a bubble. This may be true, considering the many bankruptcies. But the opposite is equally true. The internet, with its untidy economic practice has penetrated broad areas of everyday life, and brought a change of the rules, wherever it seemed to the advantage of the shopping and consuming public that has learnt remarkably quickly to become even more choosy, moody and unpredictable, because it suddenly has decided to exercise direct control over more and more aspects of life... In contrast to the politicians on television, the public no longer sticks by the rules." <www.perlentaucher.de>, September 14th, 2002.

21. Using the historical moment of the fin de siècle as our "template," it is fair to say that we are in the midst of a similar moment of turbulence and ferment. Was the digital image a phenomenon whose time had come, or one of those accidents of history? Bill Gates' famous dismissal of the internet as irrelevant uncannily repeats Antoine Lumière's equally famous prediction of the cinema as an invention without a future. 
Once again, there are uneven developments, configurations that have been quickly abandoned, or are yet to show their true potential. Take the CD-ROM. With the internet, the CD-ROM has shrunk to the function of a minor technical aid, a kind of transitional object, in its purpose replaced by the web-page, in its storage capacity obsolete. The status of the web page in turn is at once very unstable and yet has already become a fixture as apparently permanent as anything in the field of digital media. But what actually is a web-site? A personal library or a business card? An advertising billboard or a well-tended secret garden? A 24-hour convenience store or an encyclopaedia? The successor of the CD-ROM, on the other hand, the DVD, is destined for an illustrious future as it changes our film culture, viewing habits and the production/packaging of feature films at least as decisively as did the video cassette and the remote control.

22. André Bazin, after reading Georges Sadoul's Histoire du cinéma, was much impressed by the evidence that early cinema was often combined with sound, had used stereoscopic devices and featured mostly colour. "The nostalgia that some still feel for the silent screen does not go far enough back into the childhood of the seventh art. . . . Every new development added to the cinema today [i.e. in the 1950s: colour, wide-screen, 3-D] must, paradoxically, take it nearer and nearer to its origins. In short, cinema has not yet been invented!" (Bazin 1967, p. 21).

23. Charles Musser, in The Nickelodeon Era Begins (1989) as well as in his other writings has documented the determining influence of exhibition-led programming on production. A similar argument for "editorial control" retained by exhibitors, via locally customized combination of short films into a "numbers programme," is made for Germany from 1902-1912 in Müller 1994.

24. I have tried to specify some different functional equivalents for the same transition in the case of German cinema of the 1910s in my introduction to A Second Life: German Cinema's First Decade (Elsaesser 1998).

25. An attempt to re-think "diegesis" in relation to both early cinema and television can be found in Burch 1982.

26. I am not proposing a Hegelian dialectic that would run from chronology to genealogy to archaeology. Nor am I thinking of successive steps as in the old tripartite divisions from silent to sound to colour, or from primitive to classical to post-classical. More appropriate might be a model such as that of Greimas, which offers a quite different conceptual structure and space, for representing the conditions of possibility of meaning, while also indicating the boundaries of a particular way of thinking. A precedent might be Warren Buckland's "translation" of Tom Gunning's theory of genres: where single shot/non-continuity and continuity/discontinuity are arranged so as to maintain between the four terms the three relations of contradiction, contraries, and implication that make up a semiotic square (Buckland, unpublished lecture).

27. In joining the apparatus and narrative to the spectator's actual and imaginary location, I may be following Francesco Casetti who in Inside the Gaze/Dentro lo sguardo sets up a comparable typology of variables, correlating certain types of shots with specific enunciative positions on the part of the spectator.

28. An overview of the challenge posed by the moving image in the museum space can be found in Breitwieser 1996.

29. The contrasting and complementary possibilities of linking narration, enunciation and diegetic spaces are already envisaged by André Gaudreault, in his different essays on "monstration."

30. See Gunning 1989. 


\section{BIBLIOGRAPHICAL REFERENCES}

Bazin 1967: André Bazin, "The Myth of Total Cinema," in What is Cinema, Berkeley, University of California Press, 1967.

Benjamin 1978: Walter Benjamin, Illuminations, New York, Schocken Books, 1978.

Boddy 2004: William Boddy, New Media and Popular Imagination. Launching Radio, Television, and Digital Media in the United States, Oxford, Oxford University Press, 2004.

Breitwieser 1996: Sabine Breitwieser (ed.), White CubelBlack Box, Vienna, EAGenerali Foundation, 1996.

Buckland 1999: Warren Buckland, "Between Science Fact and Science Fiction: Spielberg's Digital Dinosaurs, Possible Worlds, and the New Aesthetic Realism," Screen, Vol. 40, no. 2, 1999, pp. 177-192.

Bukatman 1993: Scott Bukatman, Terminal Identity: The Virtual Subject in Postmodern Science Fiction, Durham, Duke University Press, 1993.

Burch 1982: Noël Burch, "Narrative/Diegesis-Thresholds, Limits," Screen, Vol. 23, no. 2, 1982, pp. 16-33.

Elsaesser 1986: Thomas Elsaesser, "The New Film History," Sight and Sound, Vol. 55, no. 4, 1986, pp. 246-251.

Elsaesser 1990: Thomas Elsaesser (ed.), Early Cinema. Space, Frame, Narrative, London, BFI Publishing, 1990.

Elsaesser 1998: Thomas Elsaesser (ed.), A Second Life: German Cinema's First Decade, Amsterdam, Amsterdam University Press, 1998.

Engell 1992: Lorenz Engell, Sinn und Industrie. Einführung in die Filmgeschichte, Frankfurt, Campus, 1992.

Foucault 1977: Michel Foucault, Language, Counter-Memory, Practice, Ithaca, Cornell University Press, 1977.

Friedberg 1990: Anne Friedberg, "A Properly Adjusted Window," in Elsaesser 1990.

Friedberg 1993: Anne Friedberg, Window Shopping: Cinema and the Postmodern, Berkeley, University of California Press, 1993.

Friedberg 2000: Anne Friedberg, "The End of Cinema: Multimedia and Technological Change," in Christine Gledhill and Linda Williams (eds.), Reconstructing Film Studies, London, Edward Arnold, 2000, pp. 438-452.

Gumbrecht 1998: Hans Ulrich Gumbrecht, In 1926, Stanford, Stanford University Press, 1998.

Gunning 1989: Tom Gunning, "An Aesthetics of Astonishment: Early Film and the Incredulous Spectator," Art \& Text, no. 34, 1989, pp. 31-45.

Gunning 1990: Tom Gunning, "The Cinema of Attractions: Early Film, its Spectator and the Avant-Garde," in Elsaesser 1990, pp. 56-62.

Hansen 1991: Miriam Hansen, Babel \& Babylon, Cambridge, Harvard University Press, 1991.

Hansen 1993: Miriam Hansen, "Early Cinema, Late Cinema: Permutations of the Public Sphere,” Screen, Vol. 34, no. 3, 1993, pp. 197-210.

Müller 1994: Corinna Müller, Frühe deutsche Kinematographie, Stuttgart, Metzler, 1994.

Musser 1989: Charles Musser, The Nickelodeon Era Begins, Berkeley, University of California Press, 1989.

Russell 1999: Catherine Russell, "Parallax Historiography and the Flâneur: Intermediality in Pre-and Post-Classical Cinema," Communication, March, 1999. 
Russell 2000 : Catherine Russell, "L'historiographie parallaxiale et la flâneuse: le cinéma pré- et postclassique," Cinémas, Vol. 10, nos. 2-3, 2000, pp. 151-168.

Sobchack 1987: Vivian Sobchack, Screening Space: The American Science Fiction Film, New York, Ungar, 1987.

Wedel 2002: Michael Wedel, "Schiffbruch mit Zuschauer. Das Ereigniskino des Mime Misu," in Thomas Elsaesser and Michael Wedel (eds.), Kino der Kaiserzeit, Munich, Text + Kritik, 2002, pp. 197-252.

Zielinski 1999: Siegfried Zielinski, Audiovisions, Amsterdam, Amsterdam University Press, 1999. 